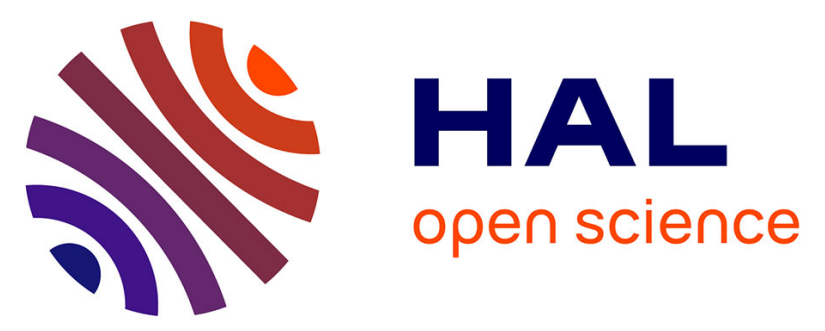

\title{
Multidimensional analysis of landscape dynamics in a Central African forest-savannah mosaic
}

Christophe Demichelis, Johan Oszwald, Clélia Gasquet-Blanchard, Victor Narat, Jean-Christophe Bokika, Flora Pennec, Tamara Giles-Vernick

\section{To cite this version:}

Christophe Demichelis, Johan Oszwald, Clélia Gasquet-Blanchard, Victor Narat, Jean-Christophe Bokika, et al.. Multidimensional analysis of landscape dynamics in a Central African forest-savannah mosaic. African Journal of Ecology, 2020, 58 (4), pp.692-708. 10.1111/aje.12750 . hal-02634114

\author{
HAL Id: hal-02634114 \\ https://hal.science/hal-02634114
}

Submitted on 30 Nov 2020

HAL is a multi-disciplinary open access archive for the deposit and dissemination of scientific research documents, whether they are published or not. The documents may come from teaching and research institutions in France or abroad, or from public or private research centers.
L'archive ouverte pluridisciplinaire HAL, est destinée au dépôt et à la diffusion de documents scientifiques de niveau recherche, publiés ou non, émanant des établissements d'enseignement et de recherche français ou étrangers, des laboratoires publics ou privés.

\section{(ㅇ)(1) $\$$}

Distributed under a Creative Commons Attribution - NonCommerciall 4.0 International 


\section{Title: Multidimensional analysis of landscape dynamics in a}

\section{Central African forest-savanna mosaic}

\section{Short title: Landscape analysis of a forest-savanna mosaic}

Authors: Christophe Demichelis ${ }^{1 *}$, Johan Oszwald ${ }^{2}$, Clélia Gasquet-Blanchard ${ }^{1,3}$, Victor Narat $^{4,5}$, Jean-Christophe Bokika ${ }^{6}$, Flora Pennec ${ }^{5}$, Tamara Giles-Vernick ${ }^{4}$

${ }^{1}$ Université de Rennes, Laboratoire ESO-UMR CNRS 6590, Rennes, France

${ }^{2}$ Université de Rennes, Laboratoire LETG-UMR CNRS 6554, Rennes, France

${ }^{3}$ Ecole des Hautes Etudes en Santé Publique, Rennes, France

${ }^{4}$ Institut Pasteur, Unité d'Anthropologie et Ecologie de l'Émergence des Maladies, Paris, France

${ }^{5}$ CNRS, MNHN, Paris Diderot, Paris, France

${ }^{6}$ ONG Mbou-Mon-Tour, Nkala, République Démocratique du Congo

*Corresponding author 1: christophe.demichelis@gmail.com

Highlights

- Integrates remote sensing and local knowledge shows landscape and land use change.

- On the Congo basin forest edge, forests progressively colonize savannas over time, with some exceptions

- Contributes to granular assessment of land cover and ecosystem service.

- Can assist conservation efforts and respect local land use practices. 


\section{ABSTRACT}

Most landscape cover assessments for conservation programs rely largely on remote sensing analyses. These analyses, however, neglect how people inhabiting protected zones perceive and structure land cover. Using socio-ecological systems (SES) analysis in a forest-savanna mosaic on the Congo basin forest edge (Democratic Republic of Congo), we investigated how human practices, landscape perceptions and land use patterns affected forest cover. We conducted remote sensing analysis using a Sentinel-2 satellite image and 187 GPS landmarks, producing a land cover map with 11 classes. Our results yielded an $81.85 \%$ correspondence with additional 164 GPS landmarks, a robust score in tropical areas. We conducted forty individual interviews, eighteen focus group discussion workshops, and nine months of participant-observation of human practices to identify 19 land units and elaborate a granular SES system structuring the landscape. Integrating local knowledge and practices with general ecological and agronomic processes, we developed a landscape dynamics model revealing progressive forest colonization of savannas. Our methods demonstrate that a forest-edge landscape cover evaluation through remote sensing and local knowledge can contribute to finer-grained assessment of land cover and ecosystem services. This assessment can assist conservation efforts by considering local populations' practices on and perceptions of landscape change.

Key words: remote sensing; local knowledge; landscape; land cover; land use; land unit; socio-ecological system. 


\section{INTRODUCTION}

Remote sensing, coupled with geographic information systems (GIS) analyses, has been useful in characterizing landscape cover, particularly in central African forests where challenging terrain can hamper on-the-ground access (Laporte et al., 1995; Mayaux et al., 1999; Mayaux \& Achard, 1999; Eva \& Lambin, 2000; Gond et al., 2003; Kerr \& Ostrovsky, 2003; Potapov et al., 2008; Gond et al., 2016). This approach has facilitated the monitoring of deforestation (Mayaux et al., 2003; N'Da et al., 2008; Demaze, 2011; Bourbier et al., 2013; Gond et al., 2016); the mapping of ecosystem services linked to biomass (Sutton \& Costanza, 2002; Gibbs et al., 2008; Clec'h et al., 2013; Barbosa et al., 2015); the monitoring of bushfires (Eva \& Lambin, 2000; Bucini \& Lambin, 2002); and more generally, anthropogenic contributions to landscape dynamics and structures (Oszwald et al., 2007; Vancutsem et al., 2009; Oszwald et al., 2015). Such analyses have contributed crucial evidence in debates about sustainable forest ecosystem management in Central Africa, debates which involve national institutions, forest companies, national and international nongovernmental organizations (NGOs), conservationists, and local populations (Mayaux et al., 2003; Mayaux et al., 2007).

Although these analyses are important, they are insufficiently detailed to characterize how people perceive and use their environment and resources over time. Most such studies have relied on remote sensing analyses, integrating knowledge of physics, ecology and agronomy to product land cover maps (Mayaux et al., 2004; Sano et al., 2010). A few recent studies in sub-Saharan Africa have integrated remote sensing with local knowledge in ecologically degraded regions (Del Rio et al., 2018; Tahir et al., 2017; Sulieman \& Ahmed, 2013; Yiran et al., 2012; elsewhere, see Jiang, 2003; Kumpula et al. 2010). These contributions demonstrate that remote sensing analysis and local 
knowledge can be brought into dialogue to enrich our understanding of land units and land cover. But beyond insisting that these two types of knowledge should be interpreted together, these contributions offer no rigorous conceptualization of "local knowledge" and little justification for interpreting it alongside remote sensing data. Yiran and colleagues, for instance, bemoan the slow pace of data production where rapid land degradation occurs and assert that satellite data "will be more suitable for sustainable planning to address the problems emanating from land degradation...if it is integrated with local knowledge" (Yiran et al., 2012: 206). Sulieman and Ahmed contend that "Local communities are always aware of the environmental changes taking place in their surroundings...[which] makes it essential to integrate scientific and local knowledge so that communities are able...to respond to the challenges of degradation and environmental change..." (Sulieman \& Ahmed, 2013: 23). These researchers' insights highlight the usefulness of "local knowledge", but their lack of conceptualization hampers their ability to articulate clearly why this should be the case.

The social sciences (anthropology, history, and geography) have produced a rich literature on "local knowledge" and its relations with scientific, and specifically ecological, knowledge (Huntington, 2000; Giles-Vernick, 2002; Berkes et al., 2008; Silvano \& Valbo-Jørgensen, 2008). As Mistry \& Berardi (2016) put it, this knowledge is "local and context-specific, transmitted orally or through imitation and demonstration, adaptive to changing environments...and situated within numerous interlinked facets of people's lives". Collected among people who conceive of and use land and its resources, local knowledge has been put to multiple uses: it has been integrated into conservation programs (Gadgil et al., 1993; Moller et al., 2004); deployed to document the effects of climate change (Alexander et al., 2011; Smith \& Sharp, 2012); and used to safeguard the resilience of ecosystems and human populations (Anik \& Khan, 2012; Gómez-Baggethun 
et al., 2013; Leonard et al., 2013). Critiques have been lobbed against its evolutionary assumptions, suppositions of stasis and insularity, and undue emphasis on "formal, cognitively based schemas" (Lauer \& Aswani, 2009; Giles-Vernick et al. 2015; Gagnon \& Berteaux, 2009).

Nevertheless, put into dialogue with remote sensing data and analyses, "local knowledge" -- the fine-grained local perceptions and description of local-level practice captured through qualitative social sciences research -- can shed light on land use, landscape and land cover, particularly in equatorial Africa's rain forest. Local perceptions and practices provide granular evidence about how inhabitants see and use the ecosystems in which they live, grounding satellite images in a lived and changing local reality.

Bringing these two types of knowledge into dialogue is challenging, as multiple researchers have noted (Sulieman \& Ahmed, 2013; Yiran et al., 2012). The socioecological systems (SES) approach offers a useful framework to bring together the interacting social and ecological features that shape a landscape (Redman et al., 2004; Liu et al., 2007; Berkes et al., 2008; Ostrom, 2009). "All humanly used resources," Elinor Ostrom has argued, "are embedded in complex, socio-ecological systems...composed of multiple subsystems and internal variables within these subsystems." (Ostrom, 2009: 419) As a "field-based, microscale, interdisciplinary study design" (Paige et al. 2016), the SES approach enables us to evaluate the physical, ecological landscape through remote sensing analysis, as well as its social dimensions, reflected in local knowledge and local land use practices.

Here we use SES to conduct a multidimensional, local-scale analysis of landscape in one region on the edge of the central African Congo Basin forest in the Maï-Ndombe province 
of the Democratic Republic of Congo (DRC). We used "landscape" to refer to a portion of territory that results from the action of natural and/or human factors and their interactions (Council of Europe 2000). We argue that a multidisciplinary approach integrating remote sensing and local knowledge is especially pertinent to understanding landscape change on the Congo basin forest edge, characterized by forest-savanna complex; remote sensing alone may not sufficiently capture highly varied land cover and its changes over time in a tropical area. Understanding landscape and its dynamics, we contend, is of even more crucial importance where conservation of forest and specific animal species overlaps with human landscape use. The SES approach provides a powerful complement to remote sensing, for in a conservation zone where people depend heavily on natural resources and are implicated in landscape changes, we can identify locally-relevant land units (that is, how people perceive the landscape and divide it into sub-units) and gain access to changing land uses -- the diverse ways that human inhabitants exploit the land and its resources according landscape structure, including cultivation, hunting, fishing, gathering.

Remote sensing analysis permitted description of land cover and characterization of the dynamics of the landscape's changing physical, ecological features, but integrated with local knowledge, produces quality landscape analysis in difficult-to-assess tropical environments with wildlife conservation and human development challenges. We recommend using this SES, local-scale, multidisciplinary approach to strengthen interventions to enhance protection of the forest and its resources.

\section{MATERIALS AND METHODS}

\subsection{Study site}


We conducted the study in the North Batéké Chiefdom of the Maï-Ndombe Province (DRC). This region is situated in a forest-savanna mosaic at the edge of the Congo Basin forest (Pennec et al. 2016). This humid tropical zone experiences four seasons: a major dry season from mid-May to mid-September; a major rainy season from September to January; and one short dry season from January to March, followed by a short rainy season from March to May. Between May 2012 and May 2013, the annual rainfall was $2387 \mathrm{~mm}$ (Narat et al. 2015a). Between May 2012 and April 2014, the mean temperature at 7.00 am was $22.6^{\circ} \mathrm{C}$ (Pennec et al., 2016). Located less than 300 kilometers from the capital Kinshasa, with direct access by the Congo River, the region is a primary supplier of agricultural food for the capital, in particular maize and cassava, but also of forest products as Gnetum africanum leaves, forest snails, bushmeat and charcoal.

The region is peopled primarily by the Batio (referred to as Bateke in Lingala). This population makes a living largely through farming and hunting, but also fishing, gathering, and animal husbandry. The average human density in the chiefdom is about 15 inhabitants $/ \mathrm{km}^{2}$, but may be much lower $(<5)$ in some parts of the territory.

The study site itself, an area of approximately $1200 \mathrm{~km}^{2}\left(2^{\circ} 27^{\prime} \mathrm{S} 16^{\circ} 14^{\prime} \mathrm{E} ; 2^{\circ} 55^{\prime} \mathrm{S}\right.$ $16^{\circ} 41^{\prime} \mathrm{E}$ ), was defined by the boundaries of village territories managed by the local NGO, Mbou-Mon-Tour (MMT) (Figure 1). Since the early 2000s, MMT has managed a community forest network to promote bonobo (Pan paniscus) conservation and sustainable economic development for human inhabitants (Narat et al., 2015b). In the mid-2000s, the World Wide Fund for Nature (WWF) established a bonobo conservation and a carbon-based project, implementing new land management and natural resource exploitation restrictions and altering local land use practices. 


\subsection{Data collection}

The SES approach to landscape necessitated both qualitative and quantitative methodologies. Qualitative and quantitative data were collected during two extended missions: a three-month field visit from July to October 2016, and a second, six-month visit from May to November, 2017. Although we sought to produce a multidimensional analysis of the landscape using geomatics tools (GIS and remote sensing), qualitative data were also collected through field observations and exchanges with local populations. GIS analyses are possible without field studies, but we concur with Langlois (2008) that such analyses require immersion in the field, and by extension, should be situated in their specific social and environmental contexts.

\subsubsection{Qualitative data}

We employed qualitative social sciences methodologies, notably interviews, focus group discussions (FGDs) and participant-observations concerning ecological knowledge. We used a place-based approach to understand the social ecological contexts that people inhabit and to illuminate how they influence and are shaped by places where they live (Fleuret et al., 2019; Adams, 2017). These data constitute part of a social and physical geographical analysis, using GIS and remote sensing.

Eighteen focus group discussions (FGDs) in nine out of ten villages in the study area were conducted. We did not conduct FGDs in Makaa village because its small population could not support such discussions. Single-gender FGDs brought together eight to ten men or women between 18 and 90 years old. FGDs were conducted in Etio, the local language, with the assistance of a trained translator. These FGD workshops led to the development of a consensus classification of the structure and exploitation of the 
landscape, based on participants' concepts of different land units and land uses. Detailed notes were taken. During these FGD workshops, the use of land unit drawings and seeds enabled participants to determine the interest of the different land units in their activities. Figure 2 illustrates one these workshops. FGD workshops contributed to the development of a mixed classification of landscape structures: we integrated the participants' enumeration of different land units and their land use practices with Author 1's field observations to produce a geographical analysis of landscape dynamics.

Forty individual interviews were conducted with primarily elderly people widely recognized as knowledge holders. These interviews frequently focused on changing land uses, land units, and landscape, but imposed no limits on historical periods covered and subjects addressed.

Daily participant-observations were also conducted to verify evidence obtained in FGD workshops. Activities carried out by inhabitants were observed and described; informants were also asked to describe and name forest and savanna types where they conducted their activities. Detailed notes of these participant-observations were also taken.

Finally, regular participant-observation of informal and formal exchanges between local leaders (chiefs, NGO representatives, Local Development Committee members) was conducted.

\subsubsection{Geographical data}

Two types of geographical field data were collected. First, GPS landmarks were collected to characterize land units and landscape structure. A second set of GPS landmarks documented human activities in Bodzuna village during participant-observations. Both 
types of geographical data concretized the qualitative data collected during FGD workshops.

Two methods to collect landmarks relating to land units and landscape structure were deployed. First, surveys were carried out in sites of interest, defined by their heterogeneity. This heterogeneity was revealed in a pixel-oriented classification of a 2016 Sentinel-2 satellite image, at 10 meters accuracy. All landmarks were georeferenced using a GPS device. Each survey therefore corresponds to a homogeneous space within a radius of 30 meters around the GPS landmark, so that it could be used on Sentinel-2 satellite image and ensure a margin of error. For each survey, multiple criteria were considered: (i) soil type (terra firma or wet), (ii) canopy height, (iii) the opening of the canopy, and (iv) possible human population uses. This allowed us to determine a landscape classification based on general ecological characteristics that could be exploited by remote sensing. For control purposes, in each survey we also took multiple photographs in the direction of the four cardinal points. For the second method, the same type of survey was carried out during participant-observations: every time an informant provided the name and description of a land unit encountered, a GPS landmark was taken and the land units were reclassified within the general landscape classification.

\subsubsection{Botanical data}

Botanical data were collected in the Etio language and written using Lingala pronunciations during participant-observations and geographic data collections. These collections were premised on informants' knowledge of abundant herbaceous, tree, canopy-dominant, and pioneer species pioneer species. WWF and MMT agents experienced in conducting botanical inventories assisted with botanical identification. 
We also relied on a catalog of the more important species based Pennec et al.'s (2016) study.

\subsubsection{Remote sensing analysis}

We produced a land cover map by associating GPS landmarks, which categorized the landscape into 11 classes based on structural and botanical information, and remote sensing analysis, based on a series of pixel-oriented classifications. GPS landmarks characterizing the landscape were divided into two series: the first, composed of 187 GPS points, facilitated the production of the map, whereas the second series of 164 landmarks permitted verification of the resulting map. Analysis was carried out on a Sentinel-2 satellite image from March 4, 2017, corresponding to the end of the short dry season and the beginning of the short rainy season; the timing accounted for soil humidity and ensured minimal cloud cover. Bands selected for pixel-oriented classification had a resolution of $10 \mathrm{~m}$ to $20 \mathrm{~m}$, corresponding to wavelengths of visible and infrared light. This selection thus accounts for variations of plant biomass with high spatial resolution (Frampton et al., 2013) for calculating the NDVI (vegetation index) (Vancutsem et al., 2009) and for separating shrub savanna into two classes (Figure 3).

Another control test entailed using the GPS point data set of a vegetation census performed in 2013 in part of the study area. This census compared classes obtained through the land cover map with those obtained in the field through a vegetation census (51 50*50 meters plots), categorized forest types according to canopy, soil and herbaceous stratum (Pennec et al., 2016).

\section{RESULTS}

\subsection{Landscape structure according remote sensing}




\subsubsection{Land cover map based on Sentinel-2 satellite image}

Based on the processing chain (Figure 3) and the 187 GPS landmarks corresponding to regions of interest for each class, we produced a land cover map representing the current landscape structure (Figure 4). Each land class in this landscape is described below, detailing the structural and botanical characteristics collected in the field for each GPS landmark used and categorized according to the 11 classes. The land cover classes have been grouped into agricultural areas, savannas, transitional areas and forests in order to facilitate their description. Table 1 presents areas and proportions of all land classes. These data highlight the dominance of forest areas (51.30\%) over savanna areas (38.15\%), with $6.94 \%$ of the landscape in transition (i.e. transitioning from savanna stage to forest stage), and $3.61 \%$ of the landscape allocated to slash-and-burn agriculture.

\section{Agricultural areas}

Agricultural areas (3.61\% of the landscape) include cultivated fields and fallow land, which have largely similar structures and cannot be differentiated by remote sensing. Agricultural fields contain multiple species, including cassava (the principal crop, cultivated over four years), maize (grown during the first year of a new field), as well as groundnuts, pineapples, bananas, hemp, and solanaceous plants (tomato, eggplant, peppers). In fallow lands, Chromoleana odorata (referred to in French as poison, fleur, fontaine) and an unidentified forest fern species [enie mofuru ${ }^{1}$ ] dominate, but some young pioneer tree species, including Musanga cecropioides [mosiu] and Maprounea membranaceae [moseon] may be present.

\section{Savannas}

\footnotetext{
${ }^{1}$ All words in italics and between brackets correspond to the local names in Tio language
} 
Savannas account for over $38 \%$ of the landscape. Floodable herbaceous savannas are predominantly composed of an unidentified herbaceous species known locally as [kenon]. We identified multiple dry savannas, including an herbaceous savanna populated primarily by Hyparrhenia diplandra [mokano/molie] and an unidentified herbaceous species [mosilu]. We also delineated two shrub savannas, which contain the same species, Hymenocardia sp. [ewire] and Anona senegalensis [elolo], but which differ in shrub density. The denser shrub savanna also has greater species diversity and includes scattered Nauclea latifolia [ebunu] and Maprounea Africana [esie].

\section{Transitional areas}

We identified two transitional classes $(6.94 \%$ of the landscape) corresponding to savannas undergoing gradual colonization by forest. Chromolaena odorata and a creeping tree, Alchornea cordifolia $[\mathrm{buu}]$ formed a bushy stratum in both classes. In terra firma transitional areas, however, we found various scattered savanna shrub species, including Hymenocardia sp. [ewire] and pioneer forest species (Pentaclethra eetveldeana [esili], Anthocleista liebrechtsiana [mopon a nsio], and Musanga cecropioides [mosiu]). In contrast, the species Gaertnera paniculata [mokaonkaon] dominates the shrub stratum of wet transitional areas.

\section{Forests}

Forests account for $51.3 \%$ of the landscape. A high canopy, ranging between 30 and 40 meters for terra firma forests and approximately 30 meters for wet forests, characterizes mature forests. Large trees such as Piptadeniastrum africanum [bopfu], Klainedoxia gabonensis [nkuri] and Milletia laurentii [ebabi] dominate the canopies of terra firma mature forests. In contrast, adapted trees with stilt roots mainly structure 
wet mature forest canopies. These forests consist primarily of Uapaca sp. [esi asia] and to a lesser extent, Hallea stipulosa [mopon a muele], Gilbertiodendron dewevrei [mondiri] and Coelocaryon preussii [ngabebalu]. In wet and terra firma forests, several species of Marantaceae occur. Where the canopy is partially open, Haumania liebrechtsiana [ndzuomi] grows and can colonize tree trunks. Other tidal species are widely present in these areas, including Megaphrynium macrostachyum [nkuu/mefuu], Sarcophrynium brachystachyum [mpumpolo], Marantochloa conferta [teele], Thaumatococcus daniellii [nkuu a bontsei] and Marantochloa leucantha [makunu].

A low canopy of 15 to 20 meters high characterizes secondary forests. The canopy opening contains varied species, but pioneer tree species dominate. Pentaclethra eetveldeana [esili], Anthocleista liebrechtsiana [mopon a nsio], Xylopia aethiopica [ensia], Musanga cecropioides [mosiu] and Trema orientalis [mowei] grow in terra firma forests, whereas young Uapaca sp. [esi asia], Macaranga stautti [mokie a madza] and different Raphia species [ndele/lempuyu] structure wet forests. These forests also contain scattered young trees which will eventually dominate a mature forest canopy. Most secondary forests contain liana species, including Ancistrophyllum secundiflorum [ekaba] and Eremospatha wendlandiana [mbubi]. Finally, terra firma forests contain an herbaceous stratum largely characterized by Aframomum sp. [ntunu mofuru] and Palisota sp. [matilatili], whereas wet forest herbaceous strata are dominated by Aframomum sp. [Ntunu a bontsei] and two undetermined species [menkunko] and [matilatili a madza]. Similar to mature forests, the same Marantaceae species are scattered throughout terra firma and wet secondary forests.

\subsubsection{Quality of the land cover map}


Verification phase results are presented in Table 2. Of the 164 control points used for verification, $81.85 \%$ conform with the land cover map that we obtained. Discrepancies frequently concern classes that are close in structure and/or soil type. For instance, of the 31 control landmarks defined as terra firma mature forests, four are located in terra firma secondary forests, and three in wet mature forests.

Table 3 presents a second verification, based on a prior vegetation census (Pennec et al., 2016). Savannas and open canopy forests are well situated on our land cover map; we find strong correspondence between our classes of savannas and our agricultural fields and those of Pennec et al. (2016). Seasonally inundated forests also convene well to our map, except for two plots considered to be in terra firma mature forest and one in an agricultural field. Conversely, the sparse and mixed forest plots accounting for tree density and an herbaceous stratum with abundant Marantaceae do not correspond to the classes on the map.

\subsection{Landscape dynamics based on land units}

Focus groups, individual interviews and participant-observations revealed more finegrained landscape classes than those presented on land cover map. Local populations and [Author 1] identified several land units that composed several classes on the map, including diverse types of secondary and primary forests and several states of agricultural fields in cultivated areas. In detailing their land use practices, they also posited important changes over time that have taken place in the landscape. Note that all villages participating in FGDs identified the same land units. All descriptions are mixed categorizations: they draw from Author 1's FGD and participant-observation notes and his interpretation of local understandings of land units and uses, as well as his ecological evaluations during field visits. The mixed categorization contributes to a more 
accurate reading of the land cover map, not to an exclusively anthropological landscape analysis, which is beyond this study's scope.

\subsubsection{Land units composing agricultural areas}

We identified three land units making up forest agricultural areas: agricultural field in forest [ngunu mofuru]; young fallow land [ebvu]; and fern brushwood [ebere enie]. Informants explained that once they finished cultivating a parcel, they allowed the field to fallow. Depending on fallow length, men and women indicated that old fields may either revert to forest or be re-cultivated. Curtailed fallow times and intensive, frequent burns to prepare a field will transform it into a mono-specific area composed of forest ferns, an unidentified species called [enie mofuru]. According to an approximately 60 year-old village chief and cultivator, "The forests that are really closed to the village have disappeared because if you cultivate too much the same place it becomes the savanna, with only ferns." For local inhabitants, the appearance of this fern indicates overexploitation. Because of pressure on available land for cultivation, these parcels are frequently farmed.

Informants also identified savanna agricultural fields as land units, called ngunu nsio. Cultivated by women over a two-year period, these fields contain cassava and groundnuts. Ngunu nsio are not fallowed; instead, they regain their savanna state over the cultivation period. We grouped these fields with herbaceous dry savannas because of their structure. Women insisted, however, that they abandoned cultivation in savanna regions because of the expansion of cattle herding and the damage that bovines caused to women's fields. According to a male village elder who both cultivated and fished, "Women stopped doing agriculture in the savannas when farmers used them to raise 
livestock. Here, there is no longer a free savanna to farm. All the savannas are occupied by the breeders."

Only women in Mbee village, and to a lesser extent, in Nkoo and Tshumbiri villages, continue to practice savanna cultivation.

\subsubsection{Land units constituting the forest complex}

Three land units comprise terra firma secondary forests, and two constitute wet secondary forests in land unit categorizations. Although tree species and structures remain largely similar across these forests, local populations differentiate between them according to their herbaceous stratum and to how easily people move through the land units. [Mofuru mona] (young terra firma forests) and [mofuru madza] (young wet forests) contain more young trees structuring the canopy of future mature forests than the other types of land units composing secondary terra firma and wet forest classes. Our informants use the terms [ebere mona] for closed terra firma forests and [ebere madza] for closed wet forests, explaining that such secondary forests contain dense lianas and Marantaceae species, preventing people from moving easily. A third class of terra firma secondary forests refers to previously cultivated fields that have reverted to forest after a long fallow. This forest class, called [ebvu mofuru], is structured by multiple young tree species, which are seen as indicators of past human activity. These closed forests can evolve to mature forests over time, but do so more slowly than other secondary forests because the dense herbaceous stratum prevents young trees from developing.

Local informants during mapping workshops describe mature forests in terms of two land units that constitute both terra firma and wet mature forests. Perceptions of the 
herbaceous stratum, particularly abundant Marantaceae species and notably [Haumania liebrechtsiana] species, underlie the distinctions between these units. Informants refer to terra firma forests as [mofuru mona] and to wet forests as [mofuru madza], but forests with high densities of Marantaceae species are referred to as [mofuru mona/madza a ndzuomi]. Sometimes the population uses the term [lesene] to refer to a mature forest in which it is easy to move because it contains a sparse herbaceous stratum. Nevertheless, people emphasize that mature forest land units are dynamic, shaped by windfall or human exploitation, which opens the canopy and facilitates Marantaceae growth. They contend that partially open spaces may revert to forest.

\subsubsection{Landscape dynamics according classification based on land units and land uses}

Bringing together local environmental classifications of landscape dynamics, land units, land uses and an analysis of deforestation fronts, we can elaborate a more detailed reading of the land cover map, integrating both a more granular understanding of each class and change in landscape dynamics (Figure 5). Although more classes appear in this diagram (19 land units) than in the land cover map, the 11 classes used for remote sensing analysis and indicated in the dotted boxes are well-represented in the diagram. Thus, by combining the landscape approach using remote sensing and the systemic approach based on local knowledge, we have a more detailed understanding of the landscape, and hence of the land cover map.

Combining these different types of data with agronomic and ecological knowledge based on field observations, we find that ecological dynamics tend towards a slow, progressive transformation of savannas into forests with colonizing pioneer species, even as fire contributes to savanna maintenance and regeneration, and agriculture participates in opening the forest canopy. As a 60 year-old tracker, cultivator, hunter and fisher 
observed, "The forest attacks the savanna. For example, there was the savanna all around the director's parcel. Now there are no more, it's the forest."

The results of the workshops using land unit drawings and seeds, confirmed by participating observations, present the types of human activities carried out according to land units, which determines land uses (Table 4).

The interviews, participant-observations and workshop highlighted human activities as playing a significant role in contemporary landscape dynamics. Local informants recognize agriculture and livestock farming as activities that structure the landscape over the short term. Conversely, hunting, fishing and gathering are punctual resource exploitation activities and do not actively influence landscape dynamics and structure in the short term. In the long term, they may affect landscape dynamics and structure by exploiting key animals, plants, or fish.

Livestock activities transform the savanna into scrub areas and accelerate their colonization by forest species. Farmers therefore burn savannas to stop forest development and hence to support livestock raising, as well as to facilitate hunting and mushroom gathering. A 60 year-old tracker, cultivator, hunter and fisher explained,

The savanna is burned at the end of August to eat the mushrooms that grow afterwards. It also allows us to hunt during the rainy season [...] There may also be the reason for the breeding. To limit the advance of the forest and conserve space for animals. In a concession there may be a forest that appears in the savanna, so the farmer will burn it to prevent the forest from settling in.

Cattle herds trample herbaceous species, limiting their regeneration. Their movement over large savanna zones appears to spread seeds by zoochory (faeces and/or 
involuntary transport in hair and hooves), particularly seeds of Chromolaena odorata, facilitating scrub encroachment and eventually, forest species in savanna areas.

Figure 6 is a land cover map locating the community forest network within the landscape and includes agricultural areas, forest complex, savanna complex and markers of human presence (villages and roads).

This map highlights that agriculture activities are mainly located around villages and communication axes (roads and Congo river), where the deforestation is most apparent. The map convenes well to the recollections of an 80 year-old elder and farmer, who observed

Because of overpopulation, there are more and more fields, and therefore there are fewer forests. When I was young I used to work in the fields near here. But today with the overpopulation I can no longer cultivate close to the village. There's no more space.

Unlike in savannas, where Chromolaena odorata facilitates forest expansion, in farmed zones, species significantly curtails forest regeneration because it develops faster than tree species. Although fallowed plots can revert to forest, repeated cultivation leads to soil depletion and favors the survival of fire-resistant ferns seeds, which in turn dominate forest pioneer species and establish mono-specific fern areas. According to FGD informants, these mono-specific ferns zones have never developed into forest.

NGO programs have a significant impact on the landscape. Participant-observations and community forest visits highlighted their positive impact on forest dynamics. The creation of community forests for bonobo protection has favored forest regeneration and expansion into savanna areas. These conservation areas prohibit agriculture. As 
Figure 6 shows, very few agricultural fields are located in the community forest network. Hence, it would appear that populations largely respect this regulation. Elsewhere in the territory, particularly near populated areas, terra firma forests do appear to suffer from deforestation because of agriculture. Certain NGOs try to prevent bushfires, which play a major role in the landscape dynamics by allowing savannas to remain in their current state. By limiting this practice, then, NGOs favor the progressive colonization of savannas by pioneer forest species.

Finally, occasional wood exploitation in some terra firma mature forests by private companies also affects landscape dynamics, although to a lesser extent than other interventions. This timber exploitation opens up mature dry forest and facilitates Marantaceae colonization. Its effects resemble those of windfall in dry and humid forests. During FGDs, informants insisted that Marantaceae forests can be maintained over long periods, depending on exploitation frequency and ecological conditions. Such forests eventually recover as dense, mature forest.

\section{DISCUSSION}

Using an SES approach, this investigation conducted a multidimensional, local-scale analysis of landscape in one region on the edge of the central African Congo Basin forest in the Maï-Ndombe province of DRC. It sought to evaluate the physical ecological landscape through remote sensing analysis in dialogue with local conceptions of the environment and local land use practices (Redman et al., 2004; Liu et al., 2007; Ostrom, 2009; Paige et al., 2016). Below we present the primary methodological and land conservation implications of our analysis.

\subsection{Contributions of Sentinel-2 satellite images}


Our land cover map offers a good overview of the study site's landscape structure. The Sentinel-2 satellite images are useful in this respect. Available free of charge and offering high spatial resolution, these images permit land cover analyses on a relatively fine scale. As in the study conducted by Bolyn et al. (2018), which also used Sentinel-2 satellite imagery, our map generated high quality results, in comparison with other remote sensing publications that target many land cover classes but use other satellite image sources (Franklin \& Wulder, 2002; Salovaara et al., 2005). In our study, our GPS field marks corresponded well to the land cover map. We obtained a classification accuracy of $81.85 \%$ with a resolution of $10-20$ meters and a sampling unit of 30 meters, showing the capabilities of the Sentinel-2 satellite images to produce high quality land cover maps even at the local level. In other studies, however the correspondence percentage rarely exceeds $80 \%$ with such fine-scale sampling units, even in large areas with low satellite image resolutions (Franklin and Wulder, 2002). Salovaara et al.'s (2005) remote sensing analysis and classification of Amazonian tropical rain forest, for instance, used a Landsat ETM+ satellite image with a resolution of 30 meters to separate the forest in three classes, with a fourth class corresponding to non-forest. Their first classification using 500 meters sampling units gave an overall classification accuracy of $85 \%$, but when they reduced sample units to 200 meters, classification accuracy was significantly lower (71\%).

Remote sensing analyses, although powerful, cannot account for a landscape structural complexity nor its botanical composition, as, for instance, Pennec et al. (2016) have demonstrated in this region. Too much crucial information for understanding a more granular and dynamic landscape is lost. For this reason, we conducted a second verification comparing our land cover map with Pennec et al.'s remote sensing and botanical composition analyses. Our map results were robust. In cases where there were 
disparities, we found that temporal lags between the botanical surveys and our remote sensing analysis could account for these differences. For instance, two savanna plots were located in our land cover map's terra firma secondary forests, likely due to the temporal lag between the botanical surveys (2013) and the remote sensing analysis (2017) and the process of forest colonization. In a second case, we found two plots considered to be in terra firm mature forest and one in an agricultural field, but this discrepancy may have again resulted from the temporal lag between the studies, from variations in rainfall affecting soil humidity, or from the opening of a field in the time elapsed between the studies. The fact that the plots corresponding to sparse and mixed forests do not correspond to the classes on the land cover map highlights the limits of remote sensing. The botanical classification of Pennec et al. (2016) considers the density of trees and the herbaceous stratum, whereas remote sensing analysis only considers canopy biomass and soil humidity.

\subsection{Contributions of local knowledge and practices}

Our findings also demonstrate that to understand landscape and its dynamics, we need more than remote sensing. Within an SES framework, we built on our remote sensing analyses by integrating local ecological knowledge and human practices and to achieve a more fine-grained vision of land unit and land use. Our use of local ecological knowledge drew from a long-standing social sciences literature that assumes that landscape inhabitants are well-positioned to recognize and evaluate ecological features as they change over time (Berkes et al., 2008; Gagnon \& Berteaux, 2009; Azzurro et al., 2011; Beaudreau \& Levin, 2014).

Although in other contexts, researchers have debated the utility of local ecological knowledge (see, for example, Gilchrist et al., 2005; Chalmers \& Fabricius, 2007; Mistry \& 
Berardi, 2016), our qualitative individual interviews and workshops yielded significant refinement of land classes. These data, coupled with field observations, identified smaller scale land units that were based on local evaluations of structure, plant diversity and soil types, local practices, and local recollections of land cover changes over time. Informants detailed four agricultural land units and five forest land units which otherwise could not be captured in an exclusively remote sensing analysis. Using interviews and workshops, we found that this forest-edge environment offered multiple ecosystem services to inhabitants of this region.

Moreover, our qualitative investigation of local land units and uses allowed us to situate the landscape into a dynamic historical context and to identify specific historical changes. Both livestock farming and agroforestry intensification were especially important factors influencing landscape dynamics (Fairhead \& Scoones, 2005; Appiah et al. 2009). Agricultural activities are mainly concentrated around sites of human settlement and along communication axes and therefore may be drivers of deforestation, particularly in densely populated sites near the Congo river. In contrast, testimonies and field visits shows that areas heavily devoted to livestock breeding are quickly colonized by forests species, leading to the formation of large transitional areas in savanna complexes.

NGO effects on landscape dynamics must also not be neglected. Bushfire control and the establishment of community forests appear to be two actions influencing these landscape dynamics. The location of agricultural fields within the landscape shows that community forests are mostly composed of large forest areas, with very few cultivated fields. Moreover, participant-observations and interviews suggest that the hunting ban in these areas is well-respected by local populations, although further study of local 
conservation policies is needed. These observations indicate that community forests to protect bonobo habitats from agriculture-related deforestation, however, may have a positive effect, thus supporting claims that NGOs can foster and enforce "rules of good conduct" (Agrawal \& Ostrom, 2001; Roth, 2004; West, 2006; West et al., 2006).

Our approach thus confirms similar studies conducted elsewhere in Africa, demonstrating the contributions of local assessments of and practices in landscapes in transition to remote sensing analyses (Sulieman \& Ahmed, 2013; Yiran et al., 2012).

\subsection{Usefulness of an integrated remote sensing-field observations approach}

Citing the world's pressing concerns of "controlling deforestation and reducing carbon dioxide emissions," Mistry and Berardi (2016) have made a compelling argument for the importance of local ecological knowledge. They contend that any effort to solve realworld problems should first engage with those local communities that are most affected, beginning from the perspective of indigenous knowledge and then seeking relevant scientific knowledge - not to validate indigenous knowledge, but to expand the range of options (Mistry \& Berardi, 2016).

Our investigation on the Congo basin forest edge highlights that our SES, local-scale, multidisciplinary approach can be used to strengthen conservation efforts to protect the forest and its resources and to enhance the resilience and well-being of local inhabitants. State and NGO policymakers using land cover maps should develop alongside such maps methods to document and understand local practices and knowledge. As Mistry \& Berardi note, these local practices and knowledge can be read in parallel with remote sensing maps, to refine them and to dialogue with local communities in order to codevelop adaptive and locally-acceptable solutions to forest protection. The Congolese 
NGO Mbou-Mon-Tour has achieved considerable support in bonobo and partial forest protection (Narat et al., 2015b). We find here that it has also beneficial effects on forest cover, even when people use these forest zones daily.

\section{CONCLUSION}

Although Alfred Korzybski's claim that "the map is not the territory" is frequently repeated, in practice, it may be easy for users of satellite imagery to forget his caveat. Field operators frequently use land cover maps to evaluate forest cover and rates of deforestation. This article demonstrates that in relying exclusively on such maps, we lose sight of socio-ecological dynamics at a local scale. We have argued here that analysis of the Congo Basin forest edge, characterized by forest and savanna complexes, multiple human uses of landscape and its resource, and conservation of forest and bonobos, required a multidisciplinary approach integrating remote sensing and SES. Our approach yielded accurate, rich insight into landscape change. Our land cover map produced good results, detailing the landscape's spatial structure with 11 land classes and yielding an $81.85 \%$ correspondence with a second series of GPS landmarks. But when we considered local knowledge of land units and uses, as well as Christophe Demichelis's observations, we identified 19 land units.

Accounting for this kind of local knowledge therefore produces a more fine-grained analysis of landscape than a land cover map alone. It convenes better to local realities and reveals how local populations use their landscape. Where people depend heavily on natural resources, such insight is of crucial importance for developing effective biodiversity protection that accommodates local populations' expectations and practices. We therefore show that integrating local knowledge of land use and ecological can refine our collective spatial and temporal understanding of landscape dynamics. 
Additionally, this approach can align conservation efforts more effectively with local practices, and in turn elicit more concrete local "buy-in" to such conservation efforts. Conservation actors should therefore integrate more systematically local population practices and perceptions into their understandings of landscape and protection to enhance the success of their protection programs.

\section{ACKNOWLEDGEMENTS}

We thank the entire Mbou-Mon-Tour team for their hospitality and support. Sincere thanks to the European Space Agency (ESA) for making the Sentinel-2 satellite images freely available. Finally, we are most grateful to all local participants in this study for their hospitality and knowledge, and especially to Miller for his daily support in the forest, the director Mamy for accommodating us at his home, and to the professor Pitshu and the director Claude for their translations during the focus groups, individual interviews and informal discussions.

\section{DATA AVAILABILITY STATEMENT}

The remote sensing image (2017 Sentinel-2 satellite image) is available online (https://earthexplorer.usgs.gov). Because of ethical committee restrictions, other data have not been publicly deposited. Upon reasonable request, the corresponding author may make available certain data following agreement by the Principal Investigator of the research project of which this study is a part.

\section{FUNDING}

This work was supported by the French National Research Agency/Agence Nationale de la Recherche [grant number ANR-14-CE31-0004] 


\section{REFERENCES}

Adams, P. (2017). "Place”. In D. Richardson, N. Castree, M.F. Goodchild, A. Kobayachi, W. Liu, R.A. Marston. International Encyclopedia of Geography. John Wiley and Sons

Agrawal, A., \& Ostrom, E. (2001). Collective Action, Property Rights, and Decentralization in Resource Use in India and Nepal. Politics \& Society, 29(4), 485-514. doi:10.1177/0032329201029004002

Alexander, C., Bynum, N., Johnson, E., King, U., Mustonen, T., Neofotis, P., ... Weeks, B. (2011). Linking Indigenous and Scientific Knowledge of Climate Change. BioScience, 61(6), 477-484. doi:10.1525/bio.2011.61.6.10

Anik, S. I., \& Khan, M. A. S. A. (2012). Climate change adaptation through local knowledge in the north eastern region of Bangladesh. Mitigation and Adaptation Strategies for Global Change, 17(8), 879-896. doi:10.1007/s11027-011-9350-6

Appiah, M., Blay, D., Damnyag, L., Dwomoh, F. K., Pappinen, A., \& Luukkanen, O. (2009). Dependence on forest resources and tropical deforestation in Ghana. Environment, Development and Sustainability, 11(3), 471-487. doi:10.1007/s10668-007-9125-0

Azzurro, E., Moschella, P., \& Maynou, F. (2011). Tracking Signals of Change in Mediterranean Fish Diversity Based on Local Ecological Knowledge. PLoS ONE, 6(9), e24885. doi:10.1371/journal.pone.0024885

De Araujo Barbosa, C. C., Atkinson, P. M., \& Dearing, J. A. (2015). Remote sensing of ecosystem services: A systematic review. Ecological Indicators, 52, 430-443. doi:10.1016/j.ecolind.2015.01.007 
Beaudreau, A. H., \& Levin, P. S. (2014). Advancing the use of local ecological knowledge for assessing data-poor species in coastal ecosystems. Ecological Applications, 24(2), 244-256. doi:10.1890/13-0817.1

Berkes, F., Colding, J., Folke, C. (2008). “Introduction”. In Berkes, F., Colding, J., Folke, C. Navigating Social-Ecological Systems: Building Resilience for Complexity and Change. Cambridge University Press. doi:10.1017/cbo9780511541957.003

Bertrand, G. (1978). Le paysage entre la nature et la société. Revue géographique des Pyrénées et du Sud-Ouest, 49(2), 239-258. doi:10.3406/rgpso.1978.3552

Bolyn, C., Michez, A., Gaucher, P., Lejeune, P., and Bonnet, S. (2018). Forest mapping and species composition using supervised per pixel classification of Sentinel-2 imagery. Biotechnologie, Agronomie, Société et Environnement, 22(3), 172-187. doi: $10.25518 / 1780-4507.16524$

Bourbier, L., Cornu, G., Pennec, A., Brognoli, C., and Gond, V. (2013). Large-scale estimation of forest canopy opening using remote sensing in Central Africa. Bois et Forêts des Tropiques, 315, 3-9. doi : 10.19182/bft2013.315.a20537

Bucini, G., \& Lambin, E. F. (2002). Fire impacts on vegetation in Central Africa: a remotesensing-based statistical analysis. Applied Geography, 22(1), 27-48. doi:10.1016/s01436228(01)00020-0

Chalmers, N., \& Fabricius, C. (2007). Expert and Generalist Local Knowledge about Landcover Change on South Africa's Wild Coast: Can Local Ecological Knowledge Add Value to Science? Ecology and Society, 12(1). doi:10.5751/es-01977-120110 
Clec'h, S.L., Oszwald, J., Jégou, N., Dufour, S., Cornillon, P.A., Miranda, I. de S., Gonzaga, L., Grimaldi, M., Gond, V., and Sartre, X.A. de (2013). Cartographier le carbone stocké dans la végétation: perspectives pour la spatialisation d'un service écosystémique. Bois \& Forêts des Tropiques, 316, 35-47. doi:10.19182/bft2013.316.a20529

Council of Europe (2000). Convention européenne du paysage, STE $n^{\circ} 176$, Florence, Italie.

Del Rio, T., Groot, J.C.J., DeClerck, F. Estrada-Carmona, N. (2018). Integrating local knowledge and remote sensing for eco-type classification map in the Barotse Floodplain, Zambia. Data in Brief, 19, 2297-2304. doi: https://doi.org/10.1016/j.dib.2018.07.009

Demaze, M.T. (2011). La télédétection en tant qu'outil de mesure de la réduction de la déforestation (REDD). Revue Télédétection, Recherche et Application, 9, 245-257.

Eva, H., \& Lambin, E. F. (2000). Fires and land-cover change in the tropics:a remote sensing analysis at the landscape scale. Journal of Biogeography, 27(3), 765-776. doi:10.1046/j.1365-2699.2000.00441.x

Fairhead, J., \& Scoones, I. (2005). Local knowledge and the social shaping of soil investments: critical perspectives on the assessment of soil degradation in Africa. Land Use Policy, 22(1), 33-41. doi:10.1016/j.landusepol.2003.08.004

Fleuret S., Gasquet-Blanchard C., Hoyez A. C. (2019). 26 mots pour la géographie de la santé. In Abécédaire de la géographie de la santé : dimension territoriale de la santé. Materiologiques. halshs-02408807

Frampton, W. J., Dash, J., Watmough, G., \& Milton, E. J. (2013). Evaluating the capabilities of Sentinel-2 for quantitative estimation of biophysical variables in vegetation. ISPRS 
Journal of Photogrammetry and Remote Sensing, 82, 83-92. doi:10.1016/j.isprsjprs.2013.04.007.

Franklin, S. E., \& Wulder, M. A. (2002). Remote sensing methods in medium spatial resolution satellite data land cover classification of large areas. Progress in Physical Geography: Earth and Environment, 26(2), 173-205. doi:10.1191/0309133302pp332ra Gadgil, M., Berkes, F., \& Folke, C. (1993). Indigenous Knowledge for Biodiversity Conservation. Ambio, 22(2/3), 151-156. http://www.jstor.org/stable/4314060

Gagnon, C. A., \& Berteaux, D. (2009). Integrating Traditional Ecological Knowledge and Ecological Science: a Question of Scale. Ecology and Society, 14(2). doi:10.5751/es02923-140219

Gibbs, H. K., Brown, S., Niles, J. O., \& Foley, J. A. (2007). Monitoring and estimating tropical forest carbon stocks: making REDD a reality. Environmental Research Letters, 2(4), 045023. doi:10.1088/1748-9326/2/4/045023

Gilchrist, G., Mallory, M., \& Merkel, F. (2005). Can Local Ecological Knowledge Contribute to Wildlife Management? Case Studies of Migratory Birds. Ecology and Society, 10(1). doi:10.5751/es-01275-100120

Giles-Vernick, T. (2002). Cutting the vines of the past: environmental histories of the Central African rain forest. University of Virginia Press.

Giles-Vernick, T., Owona-Ntsama, J., Landier, J., \& Eyangoh, S. (2015). The puzzle of Buruli ulcer transmission, ethno-ecological history and the end of "love" in the Akonolinga district, Cameroon. Social Science \& Medicine, 129, 20-27. doi:10.1016/j.socscimed.2014.03.008 
Gómez-Baggethun, E., Corbera, E., \& Reyes-García, V. (2013). Traditional Ecological Knowledge and Global Environmental Change: Research findings and policy implications. Ecology and Society, 18(4). doi:10.5751/es-06288-180472

Gond, V., Féau, C., and Pain-Orcet, M. (2003). Télédétection et aménagement forestier tropical: les pistes d'exploitation. Bois et Forêts des Tropiques, 275, 29-36. doi: 10.19182/bft2003.275.a20206

Gond, V., Cornu, G., Viennois, G., Betbeder, J., Rejou-Mechain, M., Fayolle, A., GourletFleury, S., Baghdadi, N., Barbier, N., and Mortier, F. (2016). De l'arbre au satellite: comment cartographier la diversité des forêts tropicales d'Afrique Centrale? In Botanists of the twenty-first century: roles, challenges and opportunities. Rakotoarisoa Noëline R. (ed.), Blackmore Stephen (ed.), Riera Bernard (ed.). http://agritrop.cirad.fr/580679/

Huntington, H. P. (2000). Using Traditional Ecological Knowledge in Science: Methods and Applications. Ecological Applications, 10(5), 1270. doi:10.2307/2641282

Jiang, H. (2003). Stories Remote Sensing Images Can Tell: Integrating Remote Sensing Analysis With Ethnographic Research in the Study of Cultural Landscapes. Human Ecology, 31(2), 215-232. doi: 10.1023/A:1023980713048

Kerr, J. T., \& Ostrovsky, M. (2003). From space to species: ecological applications for remote sensing. Trends in Ecology \& Evolution, 18(6), 299-305. doi:10.1016/s0169$5347(03) 00071-5$

Kumpula, T., Forbes, B. C., \& Stammler, F. (2010). Remote Sensing and Local Knowledge of Hydrocarbon Exploitation: The Case of Bovanenkovo, Yamal Peninsula, West Siberia, Russia. ARCTIC, 63(2). doi:10.14430/arctic972 
Langlois, E. (2008). SIG et terrain: antinomie ou complémentarité dans le développement d'une Recherche-Action en géomatique?. In À travers l'espace de la méthode : les dimensions du terrain en géographie. halshs-00391195

Laporte, N., Justice, C., \& Kendall, J. (1995). Mapping the dense humid forest of Cameroon and Zaire using AVHRR satellite data. International Journal of Remote Sensing, 16(6), 1127-1145. doi:10.1080/01431169508954467

Lauer, M., \& Aswani, S. (2009). Indigenous Ecological Knowledge as Situated Practices: Understanding Fishers' Knowledge in the Western Solomon Islands. American Anthropologist, 111(3), 317-329. doi:10.1111/j.1548-1433.2009.01135.x

Leonard, S., Parsons, M., Olawsky, K., \& Kofod, F. (2013). The role of culture and traditional knowledge in climate change adaptation: Insights from East Kimberley, Australia. Global Environmental Change, 23(3), 623-632. doi:10.1016/j.gloenvcha.2013.02.012

Liu, J., Dietz, T., Carpenter, S. R., Folke, C., Alberti, M., Redman, C. L., ... \& Taylor, W. W. (2007). Coupled human and natural systems. AMBIO: a journal of the human environment, 36(8), 639-649. doi: 10.1579/0044-7447(2007)36[639:CHANS]2.0.C0;2

Mayaux, P. \& Achard, F. (1999). Suivi à long terme de la végétation d'Afrique Centrale à partir de l'imagerie satellitaire. In Séminaire FORAFRI de Libreville

Mayaux, P., Richards, T., \& Janodet, E. (1999). A vegetation map of Central Africa derived from satellite imagery. Journal of Biogeography, 26(2), 353-366. doi:10.1046/j.13652699.1999.00270.x 
Mayaux, P., Gond, V., Massart, M., Pain-Orcet, M., and Achard, F. (2003). Evolution du couvert forestier du bassin du Congo mesurée par télédétection spatiale. Bois et Forêts des Tropiques, 277, 45-52. doi: 10.19182/bft2003.277.a20183

Mayaux, P., Bartholomé, E., Fritz, S., \& Belward, A. (2004). A new land-cover map of Africa for the year 2000. Journal of Biogeography, 31(6), 861-877. doi:10.1111/j.13652699.2004.01073.x

Mayaux, P., Eva, H., Palumbo, I., Grégoire, J.-M., Fournier, A., \& Sawadogo, L. (2007). Apport des techniques spatiales pour la gestion des aires protégées en Afrique de l'Ouest. In Fournier et al. Quelles Aires Protégées Pour l'Afrique de l'Ouest ? 320-328. doi:10.4000/books.irdeditions.8051

Mistry, J., \& Berardi, A. (2016). Bridging indigenous and scientific knowledge. Science, 352(6291), 1274-1275. doi:10.1126/science.aaf1160

Moller, H., Berkes, F., Lyver, P. O., \& Kislalioglu, M. (2004). Combining Science and Traditional Ecological Knowledge: Monitoring Populations for Co-Management. Ecology and Society, 9(3). doi:10.5751/es-00675-090302

N’Da, H.D., N'Guessan, E.K., Wajda, M.E., and Affian, K. (2008). Apport de la télédétection au suivi de la déforestation dans le Parc National de la Marahoué (Côte d' Ivoire). Bulletin-Société Française de Photogrammétrie et de Télédétection, 8, 17-34. halshs00386032

Narat, V., Pennec, F., Simmen, B., Ngawolo, J. C. B., \& Krief, S. (2015a). Bonobo habituation in a forest-savanna mosaic habitat: influence of ape species, habitat type, and sociocultural context. Primates, 56(4), 339-349. doi: 10.1007/s10329-015-0476-0 
Narat, V., Pennec, F., \& Bisson, L. L. (2015b). Bonobo conservation as a means for local development: an innovative local initiative of community-based conservation in Democratic Republic of Congo. Journal of Primatology, 04(02). doi:10.4172/21676801.1000127

Ostrom, E. (2009). A General Framework for Analyzing Sustainability of SocialEcological Systems. Science, 325(5939), 419-422. doi:10.1126/science.1172133

Oszwald, J., Atta, J.-M.K., Kergomard, C., and Robin, M. (2007). Représenter l'espace pour structurer le temps: approche des dynamiques de changements forestiers dans le sudest de la Côte d'Ivoire par télédétection. Télédétection 7, 271-282. halshs-00437064

Oszwald, J., Gond, V., Tchiengué, B., Boucka, F.N., Dallery, D., and Garcia, C. (2015). Description des éléments paysagers des classifications d'occupation des sols. CoForTipsCameroun

Paige, S. B., Bleecker, J., Mayer, J., \& Goldberg, T. (2017). Spatial Overlap Between People and Non-human Primates in a Fragmented Landscape. EcoHealth, 14(1), 88-99. doi:10.1007/s10393-016-1194-9

Potapov, P., Yaroshenko, A., Turubanova, S., Dubinin, M., Laestadius, L., Thies, C., ... \& Karpachevskiy, M. (2008). Mapping the world's intact forest landscapes by remote sensing. Ecology and Society, 13(2). doi: 10.5751/es-02670-130251

Pennec, F., Krief, S., Hladik, A., Lubini Ayingweu, C., Bortolamiol, S., Bokika Ngawolo, J.-C., \& Narat, V. (2016). Floristic and structural vegetation typology of bonobo habitats in a forest-savanna mosaic (Bolobo Territory, D.R.Congo). Plant Ecology and Evolution, 149(2), 199-215. doi:10.5091/plecevo.2016.1157 
Redman, C. L., Grove, J. M., \& Kuby, L. H. (2004). Integrating Social Science into the LongTerm Ecological Research (LTER) Network: Social Dimensions of Ecological Change and Ecological Dimensions of Social Change. Ecosystems, 7(2). doi:10.1007/s10021-0030215-z

Roth, R. (2004). On the colonial margins and in the global hotspot: Park-people conflicts in highland Thailand. Asia Pacific Viewpoint, 45(1), 13-32. doi:10.1111/j.14678376.2004.00225.x

Salovaara, K. J., Thessler, S., Malik, R. N., \& Tuomisto, H. (2005). Classification of Amazonian primary rain forest vegetation using Landsat ETM+ satellite imagery. Remote Sensing of Environment, 97(1), 39-51. doi:10.1016/j.rse.2005.04.013

Sano, E. E., Rosa, R., Brito, J. L. S., \& Ferreira, L. G. (2010). Land cover mapping of the tropical savanna region in Brazil. Environmental Monitoring and Assessment, 166(1-4), 113-124. doi:10.1007/s10661-009-0988-4

Silvano, R. A. M., \& Valbo-Jørgensen, J. (2008). Beyond fishermen's tales: contributions of fishers' local ecological knowledge to fish ecology and fisheries management. Environment, Development and Sustainability, 10(5), 657-675. doi:10.1007/s10668008-9149-0

Smith, H. A., \& Sharp, K. (2012). Indigenous climate knowledges. Wiley Interdisciplinary Reviews: Climate Change, 3(5), 467-476. doi:10.1002/wcc.185

Sulieman, H. M., \& Ahmed, A. G. M. (2013). Monitoring changes in pastoral resources in eastern Sudan: A synthesis of remote sensing and local knowledge. Pastoralism: Research, Policy and Practice, 3(1), 22. doi:10.1186/2041-7136-3-22 
Sutton, P. C., \& Costanza, R. (2002). Global estimates of market and non-market values derived from nighttime satellite imagery, land cover, and ecosystem service valuation. Ecological Economics, 41(3), 509-527. doi:10.1016/s0921-8009(02)00097-6

Tahir, N., Hadgu, K. M., Birhane, E., Fenta, A. A., \& Gebrehiwotc, K. (2017). Local knowledge coupled with GIS and remote sensing in landscape analysis for re-greening and rehabilitation of degraded lands in south eastern zone of Tigray, Northern Ethiopia. Journal of the Dryland, 7(1), 582-597.

Vancutsem, C., Pekel, J.-F., Evrard, C., Malaisse, F., \& Defourny, P. (2009). Mapping and characterizing the vegetation types of the Democratic Republic of Congo using SPOT VEGETATION time series. International Journal of Applied Earth Observation and Geoinformation, 11(1), 62-76. doi:10.1016/j.jag.2008.08.001

West, P. (2006). Conservation is our government now: the politics of ecology in Papua New Guinea. Duke University Press.

West, P., Igoe, J., \& Brockington, D. (2006). Parks and Peoples: The Social Impact of Protected Areas. Annual Review of Anthropology, 35(1), 251-277. doi:10.1146/annurev.anthro.35.081705.123308

Yiran, G. A. B., Kusimi, J. M., \& Kufogbe, S. K. (2012). A synthesis of remote sensing and local knowledge approaches in land degradation assessment in the Bawku East District, Ghana. International Journal of Applied Earth Observation and Geoinformation, 14(1), 204-213. doi:10.1016/j.jag.2011.09.016 


\section{TABLES}

Table 1: Area extents and proportions of the 11 landscape classes composing the land cover map for the entire study area.

\begin{tabular}{lcc}
\hline \multicolumn{1}{c}{ Land cover classes } & $\begin{array}{c}\text { Area extent } \\
\left(\mathbf{k m}^{\mathbf{2}} \mathbf{)}\right.\end{array}$ & $\begin{array}{c}\text { Landscape } \\
\text { proportion (\%) }\end{array}$ \\
\hline Total agricultural areas & $\mathbf{4 3 , 7 5}$ & $\mathbf{3 , 6 1}$ \\
\hline Terra firma transitional areas & 47,82 & 3,95 \\
Wet transitional areas & 36,28 & 3,00 \\
Total transitional areas & $\mathbf{8 4 , 1 0}$ & $\mathbf{6 , 9 4}$ \\
\hline Dry herbaceous savannahs & 58,21 & 4,81 \\
Floodable herbaceous savannahs & 39,98 & 3,30 \\
Total herbaceous savannahs & 98,19 & 8,11 \\
Shrub savannahs & 180,09 & 14,87 \\
Dense shrub savannahs & 183,76 & 15,17 \\
Total shrub savannahs & 363,85 & 30,04 \\
Total savannah areas & $\mathbf{4 6 2 , 0 4}$ & $\mathbf{3 8 , 1 5}$ \\
\hline Terra firma secondary forests & 191,08 & 15,78 \\
Terra firma mature forests & 145,14 & 11,98 \\
Total terra firma forests & 336,22 & 27,76 \\
Wet secondary forests & 60,30 & 4,98 \\
Wet mature forests & 224,83 & 18,56 \\
Total wet forests & 285,13 & 23,54 \\
Total forest areas & $\mathbf{6 2 1 , 3 4}$ & $\mathbf{5 1 , 3 0}$ \\
\hline
\end{tabular}


Table 2: Verification table derived from the crossing of control GPS landmarks with the land cover map obtained from a Sentinel-2 satellite image.

\begin{tabular}{|c|c|c|c|c|c|c|c|c|c|c|c|c|c|c|}
\hline & & \multicolumn{11}{|c|}{ Land cover map } & \multirow[b]{2}{*}{ Total } & \multirow[b]{2}{*}{\begin{tabular}{|c}
$\begin{array}{c}\text { Percentage } \\
\text { of veracity } \\
(\%)\end{array}$ \\
\end{tabular}} \\
\hline & & \begin{tabular}{|c} 
Agricultural \\
areas \\
\end{tabular} & $\begin{array}{c}\text { Wet } \\
\text { secondary } \\
\text { forests }\end{array}$ & $\begin{array}{c}\text { Wet mature } \\
\text { forests }\end{array}$ & \begin{tabular}{|c|} 
Terra firma \\
secondary \\
forests \\
\end{tabular} & $\begin{array}{c}\text { Terra firma } \\
\text { mature } \\
\text { forests } \\
\end{array}$ & \begin{tabular}{|c|} 
Wet \\
transitional \\
areas \\
\end{tabular} & \begin{tabular}{|c|} 
Terra firma \\
transitional \\
areas \\
\end{tabular} & $\begin{array}{c}\begin{array}{c}\text { Dense } \\
\text { shrub } \\
\text { savannahs }\end{array} \\
\end{array}$ & $\begin{array}{c}\begin{array}{c}\text { Shrub } \\
\text { savannahs }\end{array} \\
\end{array}$ & \begin{tabular}{|c}
$\begin{array}{c}\text { Floodable } \\
\text { herbaceous } \\
\text { savannahs }\end{array}$ \\
\end{tabular} & \begin{tabular}{|c|c} 
Dry \\
herbaceous \\
savannahs
\end{tabular} & & \\
\hline \multirow{11}{*}{ 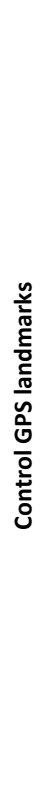 } & \begin{tabular}{|c} 
Agricultural \\
areas
\end{tabular} & 11 & & & 1 & & & & & & & & 12 & 91,7 \\
\hline & \begin{tabular}{|c|} 
Wet \\
secondary \\
forests \\
\end{tabular} & & 7 & 2 & & & 1 & & & & & & 10 & 70,0 \\
\hline & $\begin{array}{c}\text { Wet mature } \\
\text { forests }\end{array}$ & & 1 & 34 & & 5 & 1 & & & & & & 41 & 82,9 \\
\hline & \begin{tabular}{|c|} 
Terra firma \\
secondary \\
forests
\end{tabular} & & & & 18 & & 1 & 2 & & & & & 21 & 85,7 \\
\hline & \begin{tabular}{|c|} 
Terra firma \\
mature \\
forests
\end{tabular} & & & 3 & 4 & 24 & & & & & & & 31 & 77,4 \\
\hline & \begin{tabular}{|c|} 
Wet \\
transitional \\
areas \\
\end{tabular} & & & & & & & & & & & & & \\
\hline & \begin{tabular}{|c|} 
Terra firma \\
transitional \\
areas \\
\end{tabular} & & & & & & & & & & & & & \\
\hline & \begin{tabular}{|c|} 
Dense \\
shrub \\
savannahs \\
\end{tabular} & & & & & & & 2 & 9 & & & & 11 & 81,8 \\
\hline & $\begin{array}{c}\text { Shrub } \\
\text { savannahs }\end{array}$ & & & & & & & & 1 & 8 & & & 9 & 88,9 \\
\hline & \begin{tabular}{|c|} 
Floodable \\
herbaceous \\
savannahs
\end{tabular} & & 1 & & & & 1 & & & & 13 & 1 & 16 & 81,3 \\
\hline & \begin{tabular}{|c|} 
Dry \\
herbaceous \\
savannahss \\
\end{tabular} & & & & & & & & & 2 & 1 & 10 & 13 & 76,9 \\
\hline & & & & & & & & & & & & & 164 & 81,85 \\
\hline
\end{tabular}


Table 3: Location of the 51 plots addressing landscape structure and botanical composition (Pennec et al., 2016) in comparison with study land cover map using 2017 Sentinel-2 satellite imagery.

\begin{tabular}{|c|c|c|c|c|c|c|c|c|c|}
\hline & \multicolumn{8}{|c|}{ Pennec et al., 2016} \\
\hline & & Savannah & $\begin{array}{l}\text { Open canopy } \\
\text { forest }\end{array}$ & $\begin{array}{c}\text { Sparse forest } \\
\text { with } \\
\text { Marantaceae } \\
\text { understorey }\end{array}$ & $\begin{array}{l}\text { Sparse forest } \\
\text { with very dense } \\
\text { Marantaceae } \\
\text { understorey }\end{array}$ & $\begin{array}{l}\text { Mixed forest } \\
\text { with } \\
\text { Marantaceae } \\
\text { understorey }\end{array}$ & $\begin{array}{l}\text { Mixed forest } \\
\text { with open } \\
\text { understorey }\end{array}$ & $\begin{array}{c}\text { Seasonally } \\
\text { inundated forest } \\
\text { with } \\
\text { Gilbertiodendro } \\
n \text { dewevrei }\end{array}$ & $\begin{array}{c}\text { Seasonally } \\
\text { inundated mixed } \\
\text { forest }\end{array}$ \\
\hline \multirow{11}{*}{ 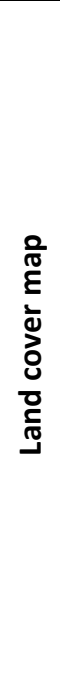 } & $\begin{array}{c}\text { Agricultural } \\
\text { complex in forest }\end{array}$ & & 2 & 1 & & & & & 1 \\
\hline & $\begin{array}{l}\text { Wet herbaceous } \\
\text { savannah }\end{array}$ & 1 & & & & & & & \\
\hline & $\begin{array}{l}\text { Dry herbaceous } \\
\text { savannah }\end{array}$ & 1 & & & & & & & \\
\hline & Shrub savannah & 1 & & & & & & & \\
\hline & $\begin{array}{c}\text { Dense shrub } \\
\text { savannah }\end{array}$ & & & & & & & & \\
\hline & $\begin{array}{c}\text { Terra firma } \\
\text { transitional zone }\end{array}$ & & & & & & & & \\
\hline & $\begin{array}{l}\text { Wet transitional } \\
\text { zone }\end{array}$ & 1 & & & 1 & & & & \\
\hline & $\begin{array}{c}\text { Terra firma } \\
\text { secondary forest }\end{array}$ & 2 & & 4 & & 4 & 1 & & \\
\hline & $\begin{array}{l}\text { Wet secondary } \\
\text { forest }\end{array}$ & & & 1 & & & & & \\
\hline & $\begin{array}{l}\text { Terra firma mature } \\
\text { forest }\end{array}$ & & & 3 & & 1 & 2 & & 2 \\
\hline & Wet mature forest & & & 5 & 1 & 1 & 5 & 4 & 6 \\
\hline
\end{tabular}

Table 4: Location of activities within the landscape based on field observations and workshops; in dark: permanent annual use; in light: seasonal or decreasing use.

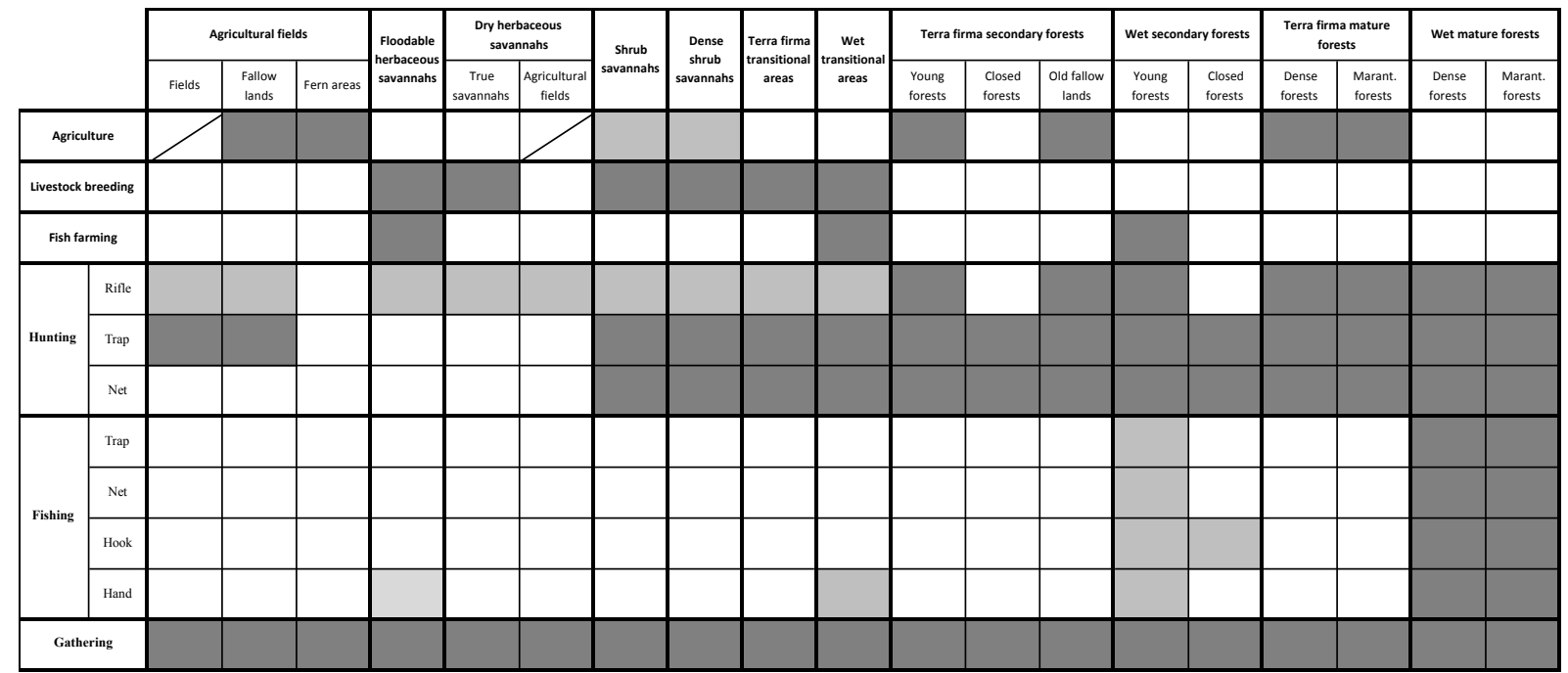




\section{FIGURE LEGENDS}

Figure 1: Study area location on the Congo Basin forest edge, North Batéké Chiefdom in the Democratic Republic of Congo.

Figure 2: Workshops using land unit drawings and seeds organized in Nkala with men (left), and in Mbee with women (right).

Figure 3: Processing chain used to classify landscape structure from a Sentinel-2 satellite image.

Figure 4: Land cover map of the study area (Sentinel-2 satellite image, 11 landscape classes).

Figure 5: Systemic approach to landscape dynamics.

Figure 6: Location of agricultural areas in relation to the community forest network and human settlement. 


\begin{tabular}{|c|c|c|}
\hline Land cover classes & $\begin{array}{c}\text { Area extent } \\
)\end{array}$ & $\begin{array}{c}\text { Landscape } \\
\text { proportion (\%) }\end{array}$ \\
\hline Total agricultural areas & 43.75 & 3.61 \\
\hline Terra firma transitional areas & 47.82 & 3.95 \\
\hline Wet transitional areas & 36.28 & 3.00 \\
\hline Total transitional areas & 84.10 & 6.94 \\
\hline Dry herbaceous savannahs & 58.21 & 4.81 \\
\hline Floodable herbaceous savannahs & 39.98 & 3.30 \\
\hline Total herbaceous savannahs & 98.19 & 8.11 \\
\hline Shrub savannahs & 180.09 & 14.87 \\
\hline Dense shrub savannahs & 183.76 & 15.17 \\
\hline Total shrub savannahs & 363.85 & 30.04 \\
\hline Total savannah areas & 462.04 & 38.15 \\
\hline Terra firma secondary forests & 191.08 & 15.78 \\
\hline Terra firma mature forests & 145.14 & 11.98 \\
\hline Total terra firma forests & 336.22 & 27.76 \\
\hline Wet secondary forests & 60.30 & 4.98 \\
\hline Wet mature forests & 224.83 & 18.56 \\
\hline Total wet forests & 285.13 & 23.54 \\
\hline Total forest areas & 621.34 & 51.30 \\
\hline
\end{tabular}




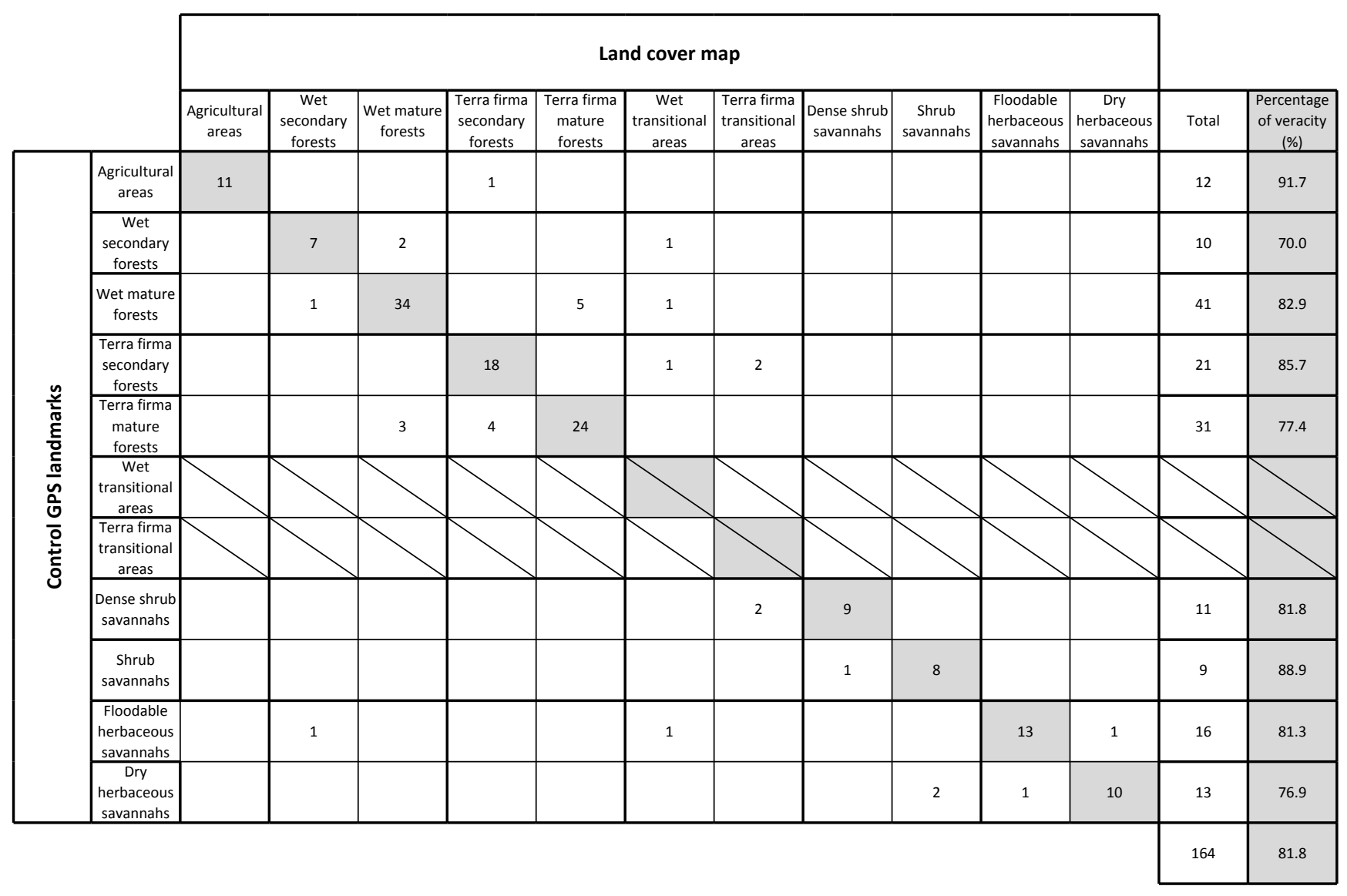




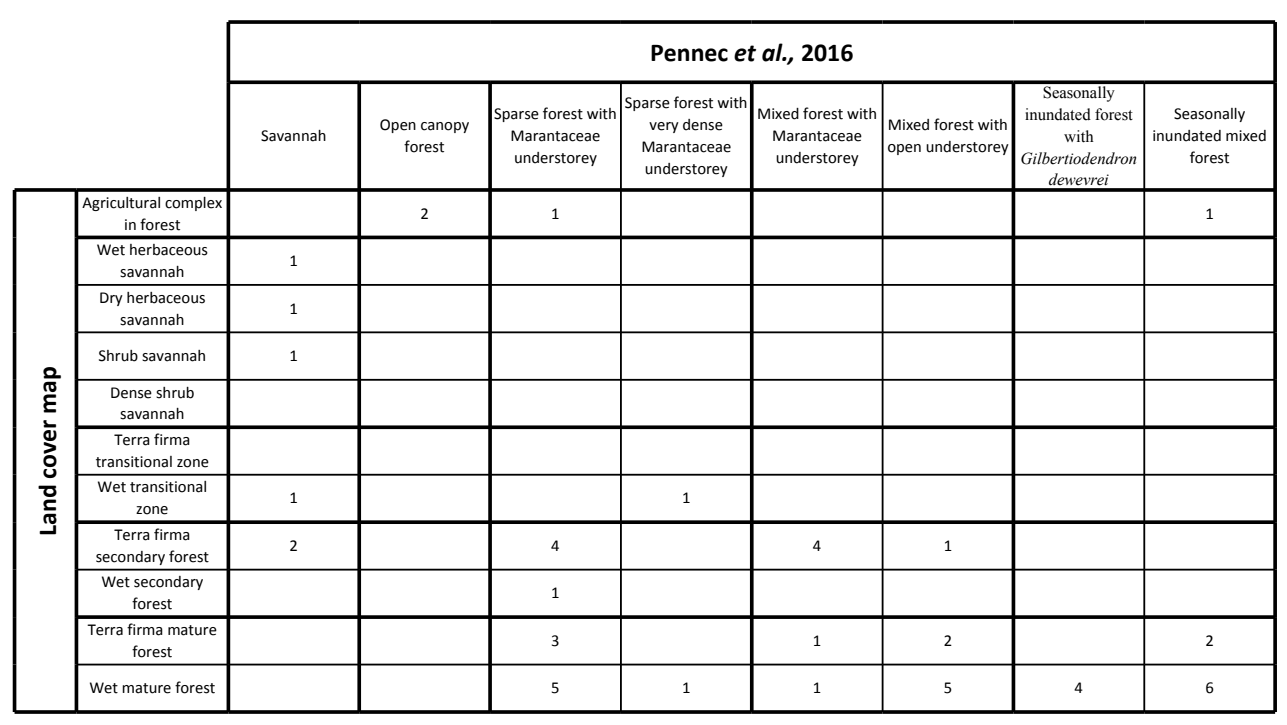




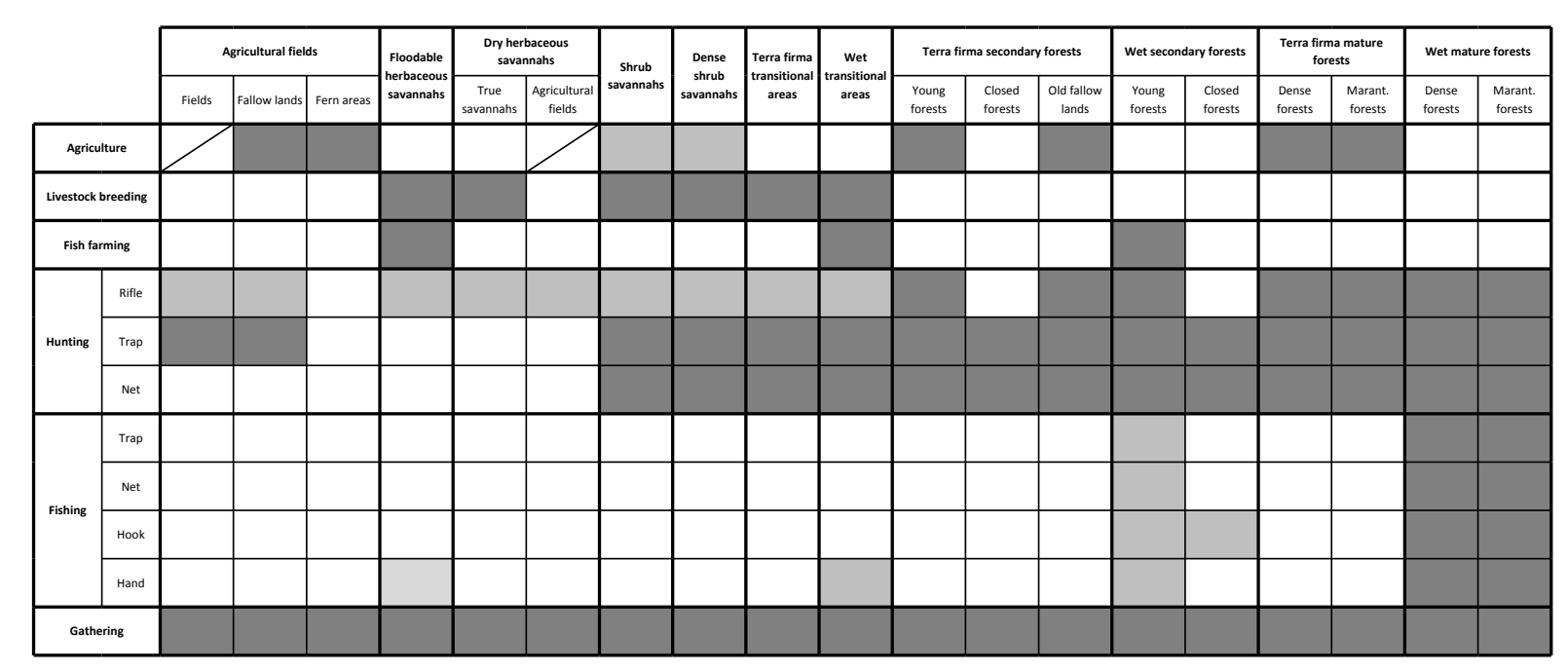




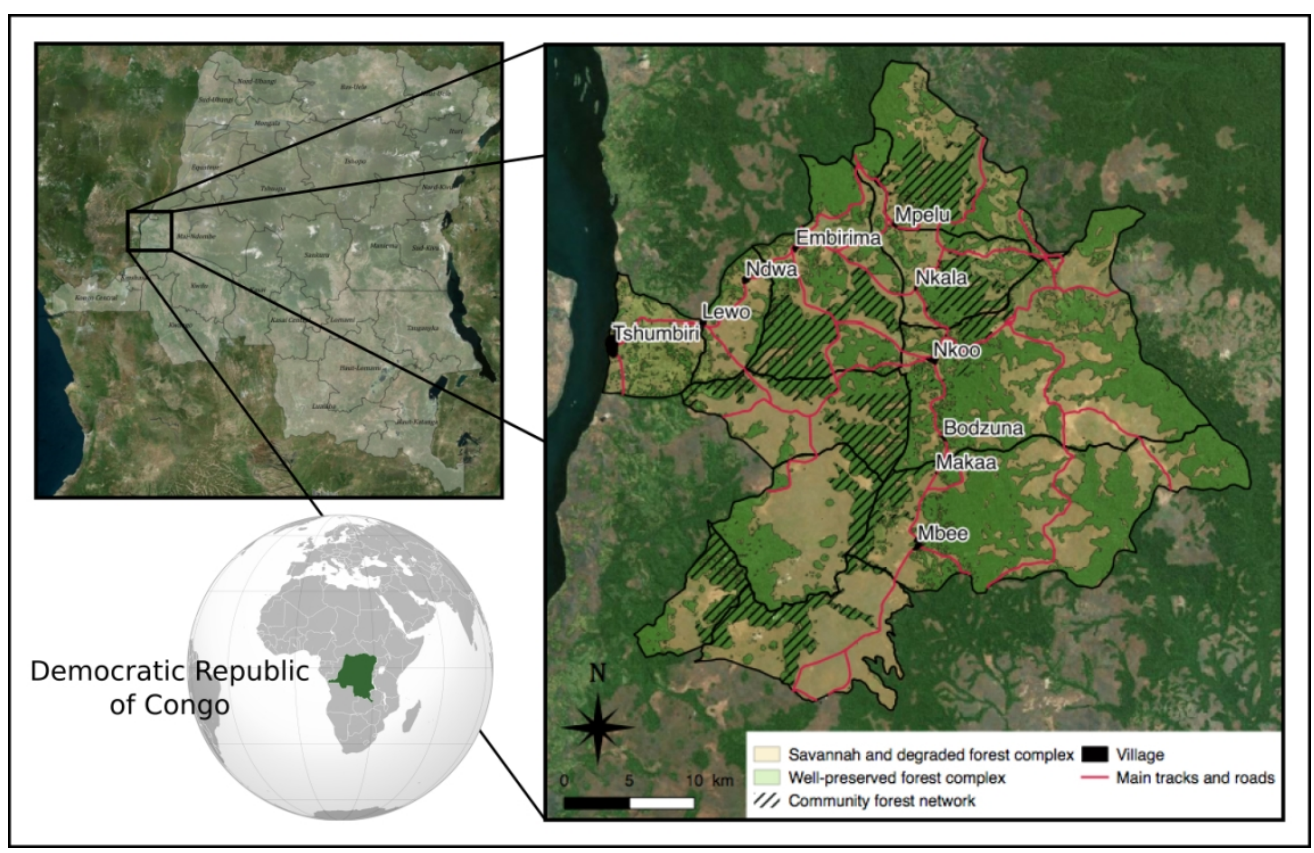

Study area location on the Congo Basin forest edge, North Batéké Chiefdom in the Democratic Republic of Congo. 


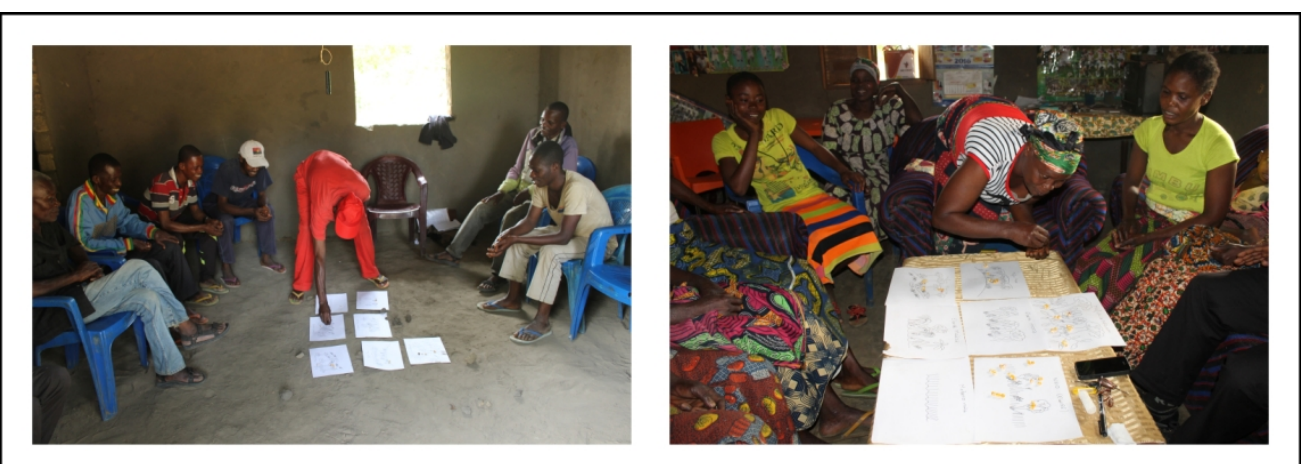

Workshops using land unit drawings and seeds organized in Nkala with men (left), and in Mbee with women (right). 


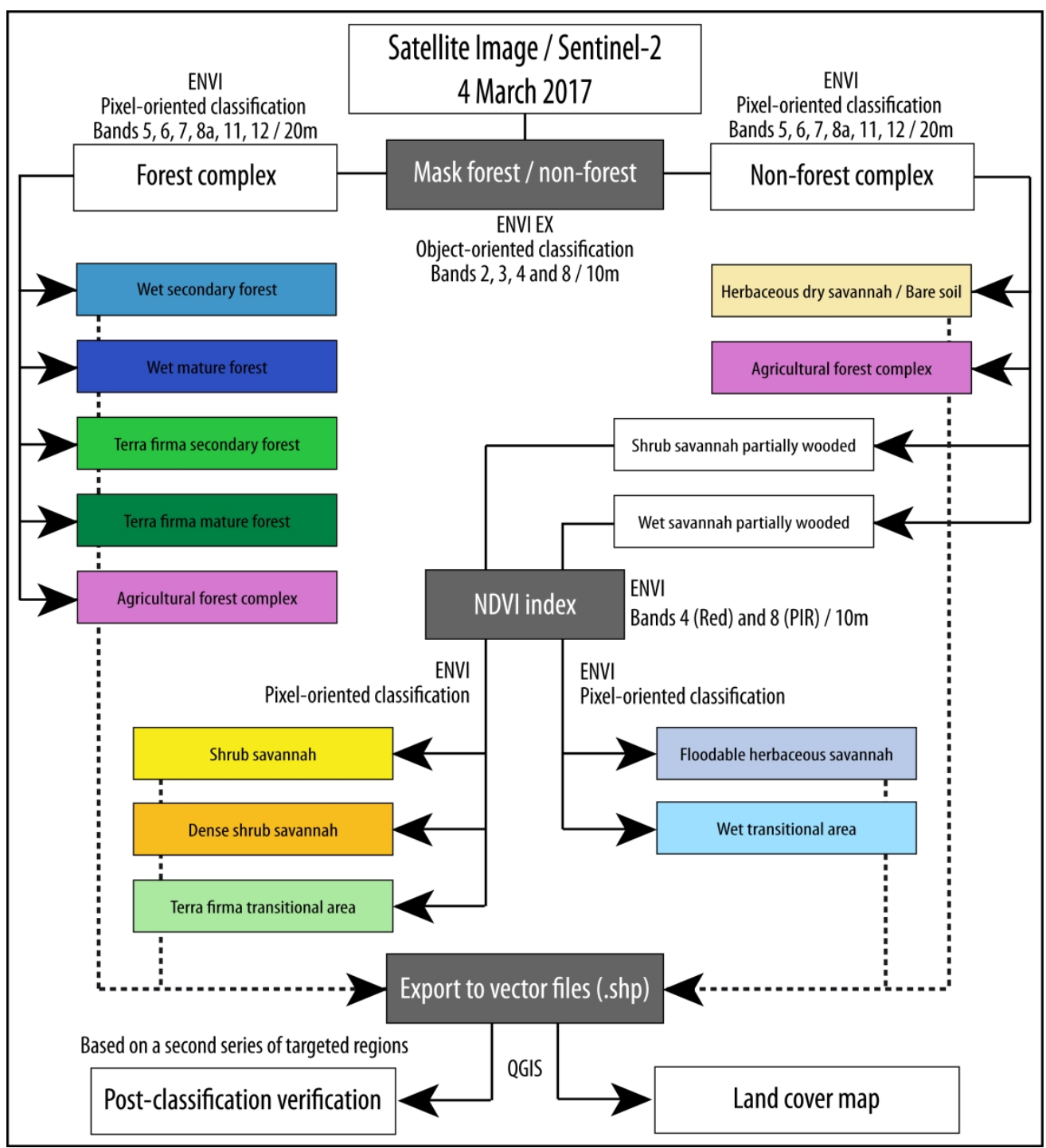

Processing chain used to classify landscape structure from a Sentinel-2 satellite image. $299 \times 328 \mathrm{~mm}(300 \times 300 \mathrm{DPI})$ 


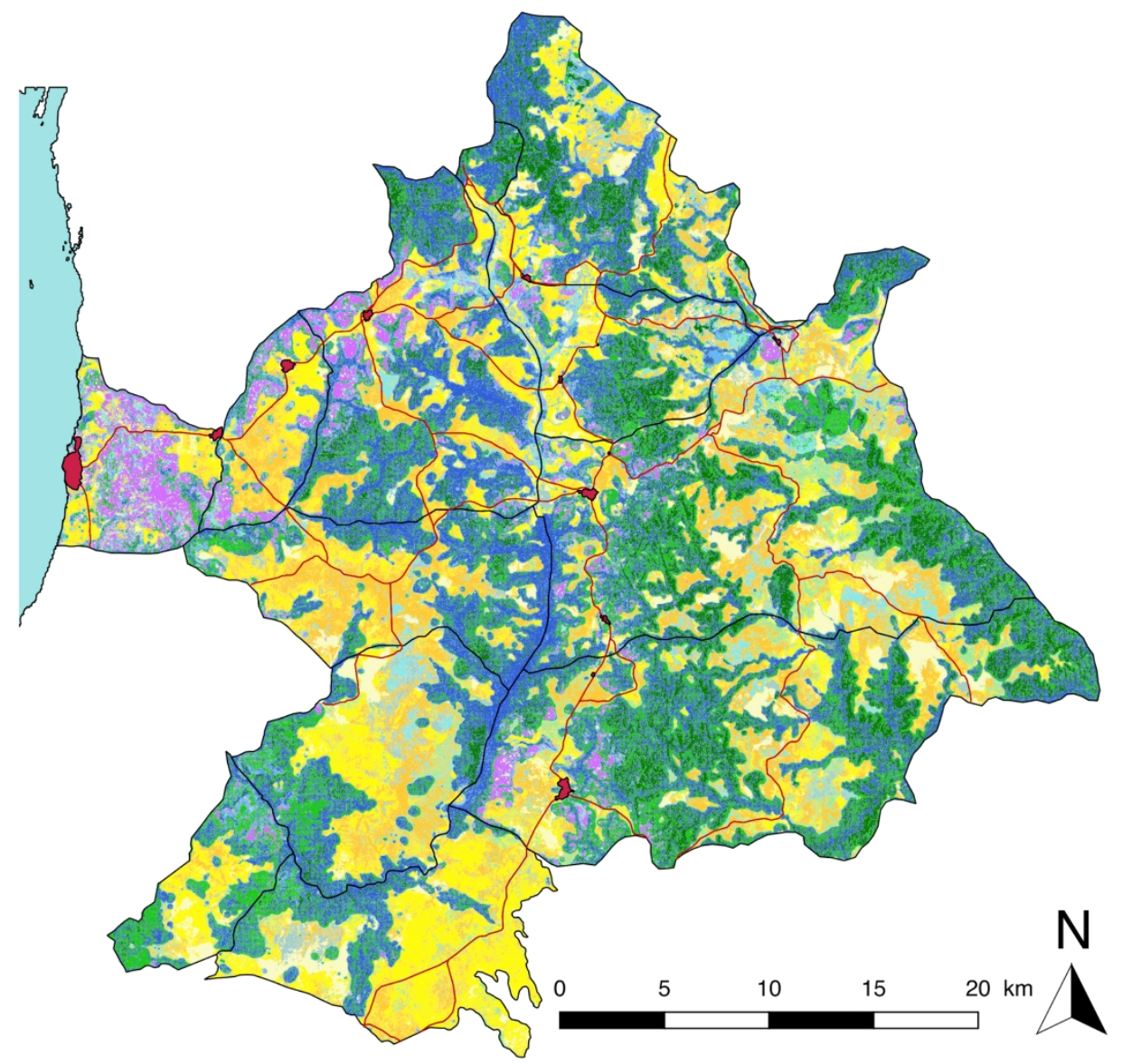

\section{Legend}

$\square$ Villages
$\square$ Main traks and roads
$\square$ Villages territories
Agricultural areas
Floodable herbaceous savannahs
Dry herbaceous savannahs
Shrub savannahs

Dense shrub savannahs Wet transitional areas Terra firma transitional areas Wet secondary forests Wet mature forests - Terra firma secondary forests - Terra firma mature forests

Land cover map of the study area (Sentinel-2 satellite image, 11 landscape classes). 


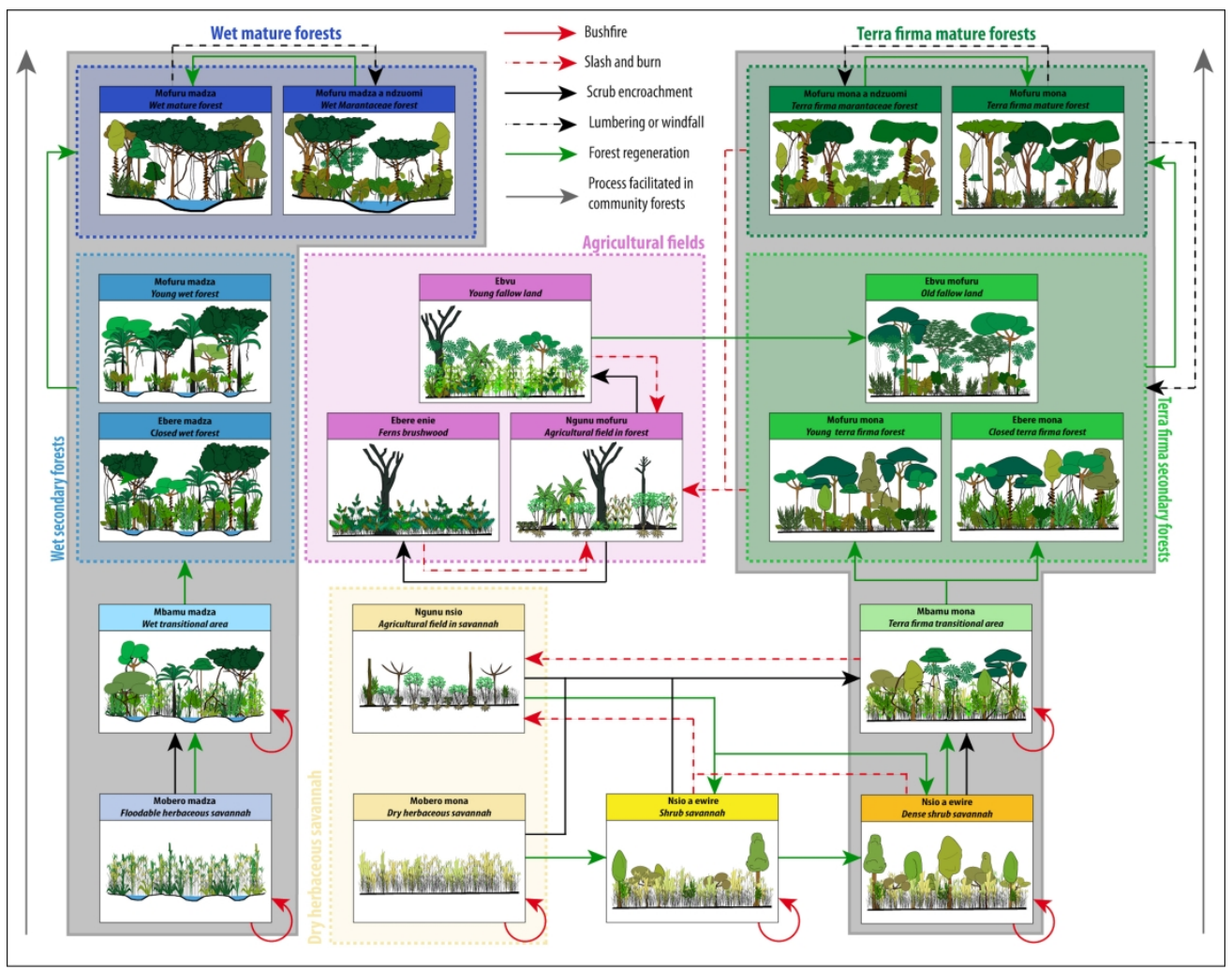

Systemic approach to landscape dynamics.

$350 \times 274 \mathrm{~mm}(300 \times 300$ DPI $)$ 


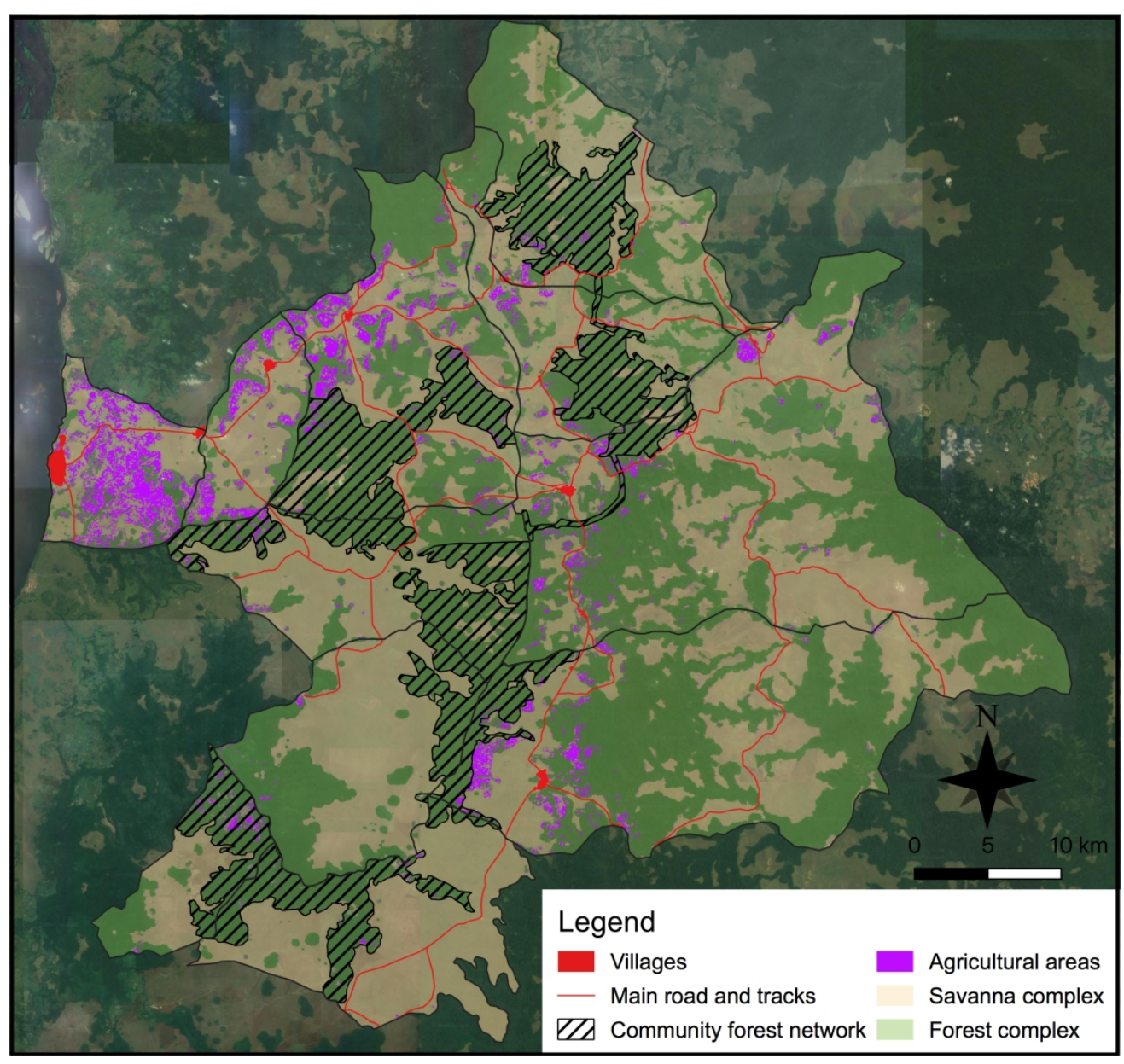

Location of agricultural areas in relation to the community forest network and human settlement. 